\title{
The relationship between the level of knowledge, attitudes and behaviour in patients with sexually transmitted diseases at Puskesmas Abang I Karangasem
}

\author{
NPDP Purnama Dewi ${ }^{1}$, Sagung Putri Permana Lestari Murdhana Putere ${ }^{1}, S$ Masyeni ${ }^{1 *}$ \\ ${ }^{1}$ Faculty of Medicine and Health Sciences, Warmadewa University \\ *masyeniputu@yahoo.com
}

\begin{abstract}
Sexually-transmitted diseases (STDs) are a group of diseases which are primarily transmitted through sexual contact. STDs easily spread from one person to another. The low level of knowledge, attitudes and behaviour of the community regarding STDs causes the case to be more of big concern. This study aimed to determine the relationship between knowledge, attitude, and behaviour in patient of STDs at Puskesmas Abang I, Karangasem. The study method used was cross-sectional analytic with questionnaires as the instrument. The variables studied were knowledge, attitude, behaviour, and occurrence of STDs. The study samples were STDs patients who visited the Puskesmas Abang I, who met the inclusion and exclusion criteria. Sampling was carried out by consecutive sampling method. The collected data were analysed by using computerized program with Chi-Square test $(\alpha=0.05)$. A total of 49 participant's was enrolled in the study. The result indicated that there was no relationship between knowledge and attitude ( $\mathrm{p}=1.000)$, knowledge and behaviour $(\mathrm{p}=0.669)$ and attitude and behaviour $(p=0.299)$. There is a need for counselling to be conducted by Puskesmas Abang I and the need for a program from the Ministry of Health to reduce the occurrence of STDs.

Keyword : Relationship, Attitudes and Behaviour, Sexually.
\end{abstract}

\section{Introduction}

Sexually transmitted disease (STD) is an infection transmit through sexual activities, pass from one to another. The STD accounted as the most cause of unpleasant diseases not only in male but also female persons Adolescents and young adults (15-24 years old) make up only $25 \%$ of the sexually active population, also prone to get STD. The causes of STD are bacteria, fungus, virus or parasite [1]. Gonorrhoea, chlamydia, syphilis, trichomoniasis, chancroid, herpes genitalis, infeksi human immunodeficiency virus, and hepatitis B are the most STD in the world [2] The clinical manifestation of STD vary, from asymptomatic, to sores, wart, or painful or frequent urination. Others symptoms are unusual discharge from penis or vagina, itching or redness on the genital area, blister or sore in or around the mouth, abnormal vaginal odour, anal itching or soreness, abdominal pain with or without fever [3]. The treatment of STD is based on the cause of the STD. Antibiotics of choice for bacterial STD are tetracycline, macrolide or quinolone [4].

People infected with STDs are 5-10 times more likely than uninfected individuals to get or transmit HIV through sexual contact. The disruption of the genital tract lining or skin 
generates a portal of access for HIV and, hence, HIV-infected individuals with other STDs are more likely to shed HIV in their genital organs

Prevention of STD by using the condom is the most effective method obtainable for males for protection against STDs. Prevention can be the key of STD control process. Education of the population, identify of symptomatic and asymptomatic people, and effective diagnosis and treatment of these patients and their partners are the key to achieve the STD control [4]. Hence the study aim is to evaluate the association between knowledge, attitude, and behavior in patient of STDs at Puskesmas Abang I, Karangasem.

\section{Method}

\subsection{Study design and setting}

A cross-sectional survey was performed in the Puskesmas Karangasem I, Bali, Indonesia, during Agustus 2017 through January 2018. The participants were selected using simple random sampling method to the people who came to the Puskesmas for another reasons. A total of 49 participants age more than 17 years old were studied..

\subsection{Sampling procedure and data analysis}

Data were obtained through direct interviews using questionnaires. The full name, participant grade or level of education, and the age of the participants were collected from participants database and cross-checked during interviews. Data were analyse with Statistical Product and Service Solution (SPSS)

\section{Results And Discussion}

Most of the participants are female. The study did not find participants with extreme old age, more than 60 years old. Detail characteristics is list in table 1.

Tabel 1. Characteristics of participants

\begin{tabular}{cc}
\hline \multicolumn{1}{c}{ Variable } & Percentage (\%) \\
\hline Gender & \\
Male & $17(34.7)$ \\
Female & $32(65.3)$ \\
Age & \\
$17-20$ & $3(6.1)$ \\
$21-30$ & $19(38.8)$ \\
$31-40$ & $23(46.9)$ \\
$41-50$ & $3(6.1)$ \\
$51-60$ & $1(2)$ \\
Level of education & \\
Un-educated & $7(14.3)$ \\
Elementary & $26(35.1)$ \\
Junior high school & $12(24.5)$ \\
High school & $2(4.1)$ \\
University & $2(4.1)$ \\
Occupation & \\
Unemployed & $34(69.4)$
\end{tabular}


Private sector $7(14.3)$

Others 8(16.3)

The most education of the participants are elementary school. The participants with civil occupation accounted in minority.

The study found knowledge, attitude and the behaviour of the participants to the STD almost appropriate. Although there are 10 (20.4) of the participants have inappropriate STD knowledge, but their behaviour in practising appropriate STD preventions are almost equal (figure 1). A half of the participants use condom to protect from STD.

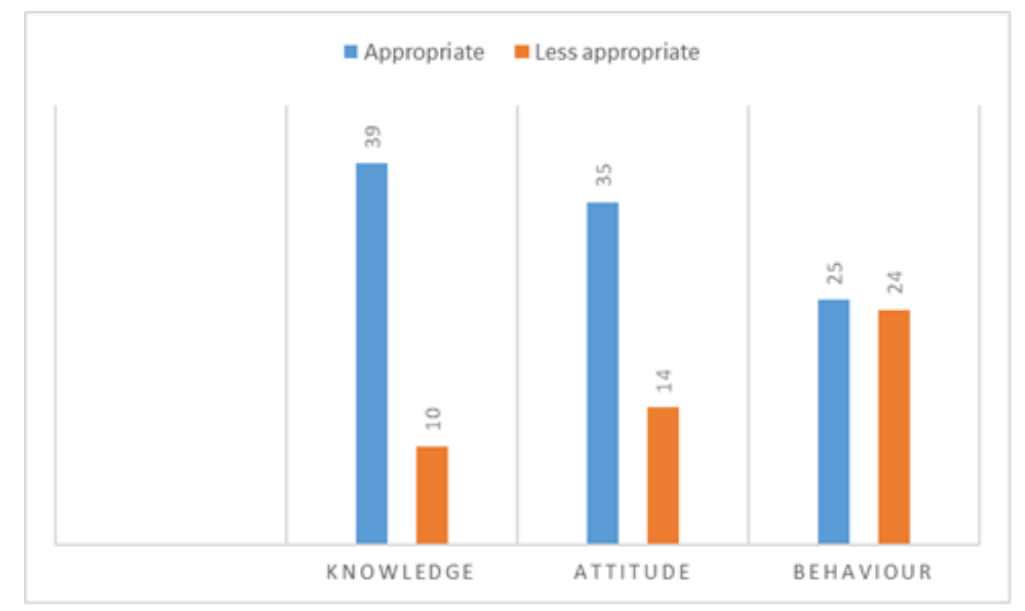

Figure 1. Profile of the participants based on study variable

Chi-square test of association between the knowledge and behaviour show no significant result $(\mathrm{p}=1.000)$ as list on table 2 . The study also did not find any association between the knowledge and attitudes of STD ( $\mathrm{p}=0.669$ ), neither of other association (attitude and behaviour), $\mathrm{p}=0.299$.

Table 2. Association between level of knowledge and behavior

\begin{tabular}{cccc}
\hline \multicolumn{1}{c}{ Variable } & \multicolumn{2}{c}{ Behaviour } & $\boldsymbol{p}$ \\
\hline Knowledge & Appropriate & Inappropriate & 1.000 \\
Appropriate & 28 & 11 & \\
Inappropriate & 7 & 3 & \\
\hline
\end{tabular}

The prevalence of STD among young adult has reported increase globally. Almost 19 million new STD cases reported in 2000, of which 48\% occur among young adult (15-24 years old) in America. The study found human papillomavirus, trichomonas's and chlamydia as the cause of STD [5]. The study found almost $80 \%$ of the participant has appropriate knowledge of STD. This finding was not in-line with the previous study where they found weak knowledge of STD. The discrepancy may relate with the gender of the participant where this study participant comprises with male and female, but the previous study only enrolled women to their study [6].

High finding of participant with proper knowledge is support with other study where they found proper or appropriate STD knowledge among participant as high as 54\% in Pontianak [7] and $51.4 \%$ in Religious region, named Demak [8]. The difference of finding may relate 
with the region of the study. The use of condom to protect from STD is relatively high in the current study, in contrast with the finding of another study in Nepal which found that the overall sexual behaviour was unsafe [9]. This finding possibly relate with the overall age of the study was older than the previous study that they studied young age participants.

The current study did not find any correlation between STD knowledge and STD attitude, in which this finding was not support with previous study [7]. Our study participant education comprises mostly with elementary school, meanwhile the other study found the most education of the participant was junior and high school which estimate has better STD knowledge.

There was no significant finding of participant's knowledge level and their behaviour. In contrast with study finding of previous study which found association between knowledge and STD behaviour in Pontianak [7] and Klaten [10]. The difference may explained with the occupation of the participant in our study was unemployed. We estimate that unemployed participant will not well informed of STD. in both others study the participant occupation was private sector, mean the have many access to get STD information's.

\section{Conclusions}

The study found proper STD knowledge but equal STD behaviour. Education may improve the knowledge, attitude and STD behaviour in order to reduce the prevalence, and morbidity of STD in community..

\section{References}

[1] Da Ros C T, and Schmitt C D S. 2007. Global epidemiology of sexually transmitted diseases. Asian J Androl,1(1):110-114

[2] Word Health Organization. 2011. Sexually Transmitted Infections. Geneva: WHO

[3] Workowski K A, and Berman S M. 2008. Sexually Transmitted Diseases Treatment guideline, 2006. MMWR, 2008;55:1-93

[4] Gharamti A A, Pinto N C, Henao-SanMartin V, Franco-Paredes C, Henao-Martínez A F. 2019. Succesful treatment of gonococcal osteomyelitis with one week of intravenous antibiotic therapy. Int J STD AIDS, 2019;30(6):610-612

[5] Weinstock H, Berman S and Cates J W. Sexually transmitted diseases among American youth: incidence and prevalence, 2000. Perspective Sex Repro Health, 2007;36(1):6-10.

[6] de Waure C, Mannocci A, Cadeddu C, Gualano M R, Chiaradia G, Vincitorio et al. Knowledge, attitude and behaviour about sexually trasmitted infections: a survey among Italian university female sudents. Epid Biostat Pub Health, 2015;12(2): DOI: 10.2427/11112

[7] Fatimah S. 2013. Hubungan Antara Pengetahuan dan Sikap Pasien Infeksi Menular Seksual (IMS) dengan Perilaku Pencegahan Penularan IMS di Wilayah Kerja Puskesmas Kom Yos Sudarso Pontianak. Fakultas Kedokteran Universitas Tanjungpura.

[8] Indahyani N. 2016. Perilaku Berisiko Infeksi Menular Seksual pada Ibu Rumah Tangga di Daerah Berbasis Agamis Demak. Fakultas Kesehatan Mayarakat Universitas Diponegoro.

[9] Upreti D, Reqmi P, Pant P, Simkhada P. Young people's knowledge, attitude and behaviour on STI/HIV/AIDS in the context of Nepal: a sistematic review. Kathmandu Univ Med J, 2009;7(28):383-91 
[10] Ningsih D I. 2016. Hubungan Pengetahuan dan Sikap dengan Perilaku Berisiko Seks Bebas Anak Jalanan di Rumah Singgah Kota Klaten. Fakultas Ilmu Kesehatan Universitas Muhammadyah Surakarta. 